\title{
Uzun süre litotomi pozisyonunda kalmaya bağlı gelişen peroneal palsi
}

\author{
Peroneal palsy due to long term lithotomy position
}

Nevsun Pıhtılı Taş

Gönderilme tarihi:15.03.2018

Kabul tarihi:23.07.2018

\section{Özet}

Peroneal sinirin tuzak nöropatisi alt ekstremitede en sık görülen tuzak nöropatidir Anatomik yapısı nedeniyel kolaylıkla bası altında kalabilir ve fibula başı seviyesinde çok yüzeyel seyrettiği için sıklıkla bası bu seviyede ortaya çıkar. Bası nedenleri arasında eksternal kompresyon, travma, uzun süre bacak bacak üzerine atma, çömelme gibi pozisyonel sebepler sayılabilir. Ayrıca normal doğum veya küretaj gibi nedenlerle uzun süre litotomi pozisyonunda kalmak nadirde olsa eksternal basıya yol açabilir. Literatürde obstetrik vakalarda nörolojik hasara bağlı alt ekstremite duyu ve motor disfonksiyon insidansı \%0.008 ile \%0.5 arasında değişmektedir. Bu yazıda küretaj sırasında uzun süre litotomi pozisyonunda kalmaya bağlı peroneal sinirin tuzaklanması olan bir olgunun klinik değerlendirme, tanı ve tedavi planı tartışılmıştır.

Anahtar Kelimeler: Litotomi, peroneal palsi.

Pıhtılı Taş N. Uzun süre litotomi pozisyonunda kalmaya bağıı gelişen peroneal. Pam Tıp Derg 2019;12:161-163.

\begin{abstract}
Entrapment neuropathy of the peroneal nerve is the most common entrapment neuropathy in the lower extremity. Because of its anatomical structure, it is it can be easily compressed and as it is very superficial at the head of the fibula, the compression most often occurs at this level. Causes of compression are external compression, trauma, long-leg position, crouching. In addition, long-term lithotomy positioning for reasons such as normal delivery or curettage may rarely lead to external compression. In the literature, the incidence of lower extremity sensory and motor dysfunction due to neurological impairment in obstetric cases ranges from $0.008 \%$ to $0.5 \%$. In this article, the clinical evaluation, diagnosis and treatment plan of a case with peroneal nerve entrapment due to prolonged lithotomy position during curettage has been discussed.
\end{abstract}

Anahtar Kelimeler: Lithotomy, peroneal palsy.

Pıhtılı Taş N. Peroneal palsy due to long term lithotomy position. Pam Med J 2019;12:161-163.

\section{Giriş}

Peroneal sinirin tuzak nöropatisi alt ekstremitede en sık görülen tuzak nöropatidir. Anatomik seyri nedeniyle dış basılara sıklıkla maruz kalır ve çok yüzeyel olduğu için bası en sık fibula başında meydana gelir. Bası nedenleri arasında eksternal kompresyon, travma, uzun süre bacak bacak üzerine atma, çömelme gibi pozisyonel sebepler sayılabilir. Ayrıca normal doğum veya küretaj gibi nedenlerle uzun süre litotomi pozisyonunda kalmak nadirde olsa eksternal basıya yol açabilir [1, 2]. Hastalarda kas güçsüzlüğüne sekonder düşük ayak ve yürüme güçlüğü gelişebilir.

Literatürde obstetrik vakalarda nörolojik testi ile değerlendirildi. Bilateral üst ekstremite, hasara bağlı alt ekstremite duyu ve motor kalça, diz ve sağ ayak bileği eklemlerinin kas disfonksiyon insidansı \%0,008 ile \%0,5 arasında gücü değerlendirmesi normalken, sol ayak bileği değişmektedir [1, 3]. Bu yazıda küretaj sırasında dorsifleksiyonu 2/5, başparmak ekstansiyonu 2/5, 
sol ayak eversiyonu 2/5 kas gücündeydi. Ayrıca sol ayak dorsumunda hipoestezisi mevcuttu. Derin tendon refleksleri normaldi, her iki taban cildi refleksi fleksör olarak tespit edildi. Hastanın stepaj yürüyüşü mevcuttu. Rutin laboratuvar tetkikleri olan tam kan sayımı, karaciğer ve böbrek fonksiyon testleri, elektrolitler, açlık kan şekeri, eritrosit sedimentasyon hızı, C- reaktif protein, tiroid fonksiyon testleri, vitamin B12 düzeyi, serum protein elektroforezi ve vaskülit paneli normaldi. Radyolojik incelemede iki yönlü diz grafisi normaldi. Elektrofizyolojik değerlendirmede motor iletim çalışmasında, sol peroneal sinirde fibula başı proksimalinden uyarımla ileti bloğu saptandı (Tablo1). Sol tibial ve sağ peroneal sinir motor ve sural sinir duyu iletim çalışması normaldi.

$\mathrm{Bu}$ bulgularla peroneal sinirin fibula başı seviyesinde kompresyon nöropatisi ile uyumlu bulunarak, hasta bir ay süre ile fizik tedavi ve rehabilitasyon programına alındı. Tedavi protokolünü 20 dakika süreyle yüzeyel ISI ardından elektrik stimülasyonu (kesikli galvanik akım 5 dakika arayla 10 dakikalık periyotlarla toplam 20 dakika) ve egzersiz programı (pasif, aktif asistif, aktif ve rezistif eklem hareket açıklığı egzersizleri) oluşturdu. Tedavi sürecinde ayak-ayak bileği stabilizasyon ortezi verildi. Tedavinin 21. gününde hastanın alt ekstremite kas gücünde tam bir düzelme gözlenemedi. Hastanın sol ayak bileği dorsifleksiyonu 3+/5 idi ve ortez kullanmadan rahatlıkla yürüyemiyordu. 3. ay kontrolünde hasta ortez kullanmadan yürüyebiliyordu. 6.ayda ise tam bir iyileşme gözlendi.

\section{Tartışma}

Tablo.1 Hastanın ENMG bulguları.

\begin{tabular}{llll}
\hline Motor & Latans $(\mathrm{ms})$ & Amp $(2-4 \mu \mathrm{V}) \mathrm{H} ı \mathrm{z}(\mathrm{m} / \mathrm{s})$ & $\mathrm{H} \mathrm{Iz}(\mathrm{m} / \mathrm{s})$ \\
\hline Sol peroneus EDB (tedavi öncesi) & & & \\
1.ayak bileği & 3,18 & 8,2 & \\
2. fibula başı & 10,60 & 6,9 & 47,9 \\
3.diz & 12,90 & 2,2 & 32,4 \\
\hline
\end{tabular}

Popliteal çukurda siyatik sinirden ayrılan peroneal sinir, çukurun dış tarafında gastroknemius kasının lateral başı üzerinden geçer. Diz altında fibula başı ve boynu civarındaki $4 \mathrm{~cm}$ ' lik bir alanda çok yüzeyel bir seyir gösteren sinir, sadece cilt ve yüzeyel fasya ile korunur [4]. Alt ekstremitede sık karşılaşılan peroneal sinir mononöropatisinde sinir en çok yüzeyel seyir gösterdiği $4 \mathrm{~cm}$ 'lik alanda sıkışmaktadır [5]. Perioperatif siyatik sinir hasarları iskemi, kardiyak cerrahi sırasındaki pozisyonlama, litotomi pozisyonu, vajinal doğum, kraniotomi veya diğer nörocerrahi operasyonlardaki uzamış oturma pozisyonu, kalça artroplastisi sırasında ve sonrasında gelişebilmektedir Düşük ayak şikayeti ile başvuran 303 hastanın tarandığı retrospektif bir çalışmada santral nedenler \%31 oranında iken, periferal nedenler \%68 oranında bulunmuştur. Periferal nedenler ise common peroneal sinir lezyonları, L5 radikülopatiler, poliradikülopatiler ve nadir olarak saf siyatik lezyonlarını içerir [6]. Hastamız nadir gelişen peroneal sinir hasarları sonrası (periferal neden) düşük ayak gelişmiş olması ile araştırılmaya değerdir. Genel olarak kabul edilmiş kanıya göre siyatik sinirin peroneal bölümü, tibial sinire göre hasarlardan daha ciddi oranda etkilenmektedir. Bunun nedenleri olarak süperfisiyal yerleşimi olması, endonöral veya perinöral desteğinin daha az olması, daha az kan akımına sahip olması ve siyatik çentik ile fibular boyun arasında dar bir alanda fikse olması düşünülmektedir [7]. Bizim hastamızda da common peroneal dal, tibial dala göre daha çok hasara uğramıştı.

Doğum esnasında peroneal nöropati yanlış pozisyonlama, litotomi pozisyonunda uzun süre kalma, dizin dışarıdan eksternal basıya maruz kalmasına bağlı olarak gelişebildiği ve litotomi pozisyonunda yapılan operasyonlardan sonra 1/3608 vakada görüldüğü bildirilmektedir $[1,8]$.

Ayrıca literatürde 991 cerrahi hasta üstünde yapılan prospektif bir diğer çalışmada sinir hasarının vücut yapısı ve diabetes mellitus gibi hastalıklardan ziyade litotomi pozisyonunda geçirilen süreye bağlı olduğu bildirilmiştir. 
Litotomi pozisyonunda uzamış operasyon süresi 2-4 saatten fazlası olarak tanımlanmaktadır [1]. Bizim olgumuzda ise 90 dakika süren litotomi pozisyonundaki kalma sonrası sinir hasarı olduğu tespit edilmiştir. Olgumuzda ek bir sistemik hastalık bulunmamaktaydı.

Tanıda en yararlı metot ENMG'dir. Elektrofizyolojik inceleme, düşük ayak ile başvuran hastalarda, öncelikle lezyonun lokalizasyonu, ayak dorsifleksiyon kaybına nedenolabileceklezyonlarınveyapolinöropatinin ayrımı açısından önemlidir [9]. Motor ve duyu iletim hızı çalışmaları her 2 ekstremitede yapılmalı ve sonuçlar karşılaştırılmalıdır. Bizim olgumuzda düşük ayak nedenleri arasında yer alabilecek radikülopati, lumbosakral pleksus lezyonu, siyatik sinir lezyonu, basınca duyarlı herediter nöropati ve polinöropati gibi nedenler öykü, aile öyküsü, fizik muayene, laboratuar bulguları, radyolojik ve elektrofizyolojik değerlendirme ile dışlanmıştır. Peroneal sinirde oluşan kompresyonun etkisi, hasarın süresi, uygulanan kuvvet ve etkilenen sinir lifi tipi ile korelasyon gösterir. Büyük miyelinli lifler, küçük miyelinsiz liflere göre daha çok hasar görür [10]. Belirli bir aktivite veya pozisyon ile ilişkili bir sıkışma söz konusu ise konservatif tedavi, genelde başarılı olabilmektedir [11]. Konservatif tedavide öncelikle steroid olmayan anti-inflamatuar ilaçlar, istirahat, fizik tedavi, predispoze faktörlerin ortadan kaldırılması, yürümeye yardımcı cihazlar ve ortezler gibi yöntemler tercih edilir [12]. Bizim olgumuzda da konservatif tedavi sonrası yanıt alındığından cerrahi tedaviye ihtiyaç duyulmamıştır.

Burada nadir görülen bir düşük ayak nedeni olarak uzun süre litotomi pozisyonuna bağlı gelişen peroneal sinir kompresyon nöropatisi olgusu literatür eşliğinde tartışılmıştır.

Sonuç olarak kompresyon nöropatilerinde prognoz genellikle iyidir ve cerrahi müdaheleye gerek kalmaksızın tam nörolojik iyileşme sağlanabilir. Bununla birlikte bu olgu litotomi pozisyonunda yapılan operasyonlarda kompresyon nöropatilerine karşı dikkatli olunması konusuna dikkat çekmek amacıyla da sunulmuştur.

Çıkar İlişkisi: Yazarlar çıkar ilişkisi olmadığını beyan eder.

\section{Kaynaklar}

1. Warner MA, Warner DO, Harper CM, Schroeder DR, Maxson PM. Lower extremity neuropathies associated with lithotomy positions. Anesthesiology 2000;93:938942.

2. Waespe W, Saurenmann E, Rageth JC. Postpartum footdrop. Frauenklinik Limmattalspital, Schlieren Schweiz Med Wochenschr 2000;130:70-71.

3. Scurr JR, Scurr JH. Common peroneal nerve injury during varicose vein surgery. Eur $\mathrm{J}$ Vasc Endovasc Surg 2006;32:334-335.

4. Watemberg N, Amsel S, Sadeh M, Lerman-Sagie T. Common peroneal neuropathy due to surfing. J Child Neurol 2000;15:420-421.

5. Lippin Y, Shvoron A, Yaffe B, Zwas ST, Tsur H. Postburn peroneal nerve palsy: a report of two consecutive cases Burns 1993;19:246-248.

6. Van Langenhove M, Pollefliet A. Vanderstraeten G. A retrospective electrodiagnostic evaluation of footdrop in 303 patients. Electromyogr Clin Neurophysiol 1989;29:145-152.

7. Flanigan RM, DiGiovanni BF. Peripheral nerve entrapments of the lower leg, ankle and foot. Foot Ankle Clin. 2011;16:255-274.

8. Scurr JR, Scurr JH. Common peroneal nerve injury during varicose vein surgery. Eur $\mathrm{J}$ Vasc Endovasc Surg 2006;32:334-335

9. Preston DC, Shapiro BE. Electromyography and neuromuscular disorders. Boston: ButterworthHeinemann, 1998;231-255.

10. Erol O, Ozçakar L, Kaymak B. Bilateral peroneal neuropathy after surgery in the lithotomy position. Aesthetic Plast Surg 2004;28:254-255.

11. Brown RE, Storm BW. Congenital common peroneal nerve compression. Ann Plast Surg 1994;33:326-329.

12. Styf J, Morberg P. The superficial peroneal tunnel syndrome. Results of treatment by decompression. J Bone Joint Surg Br 1997;79:801-803. 